\title{
Analisis Produktivitas Langkah-Langkah Siswa dalam Physics Problem Solving
}

\author{
Irma, Jusman Mansyur dan Syamsu \\ nurfiani.ma@gmail.com \\ Program Studi Pendidikan Fisika FKIP Universitas Tadulko \\ Jl. Soekarno Hatta Km.9 Kampus Bumi Tadulako Tondo Palu-Sulawesi Tengah
}

\begin{abstract}
Penelitian ini bertujuan untuk mendeskripsikan hasil analisis produktivitas langkah-langkah siswa dalam physics problem solving. Penelitian ini dilakukan pada siswa kelas XI di salah satu SMA di kota Palu. Subyek penelitian ini terdiri dari 20 orang siswa dan dipilih 6 responden dengan cara pemberian tes pemilihan responden. Data diperoleh melalui lembar jawaban siswa, rekaman thinking-aloud dan wawancara. Data penelitian dianalisis melalui pendekatan deskriptif kualitatif. Hasil penelitian ini menunjukkan bahwa langkah problem solving siswa berbeda-beda sehingga produktivitas juga rendah.
\end{abstract}

Kata Kunci: Produktivitas, Problem Solving

\section{PENDAHULUAN}

Polya mengartikan problem solving sebagai suatu usaha mencari jalan keluar dari satu kesulitan guna mencapai satu tujuan yang tidak begitu mudah segera untuk dicapai. Metode yang dilakukan masing-masing siswa berbeda dalam memecahkan masalah, walaupun masalah yang dihadapi sama, tergantung kepada individu masing-masing ${ }^{[1]}$.

Suherman menyatakan bahwa suatu masalah biasanya memuat suatu situasi yang mendorong seseorang untuk menyelesaikannya akan tetapi tidak tahu secara langsung apa yang harus dikerjakan untuk menyelesaikannya [2]. Jika suatu masalah diberikan kepada seorang anak dan anak tersebut langsung mengetahui cara menyelesaikannya dengan benar, maka soal tersebut tidak dapat dikatakan sebagai masalah bagi anak tersebut.

Secara ringkas proses problem solving meliputi langkah-langkah berikut: (1) mengumpulkan informasi dan sumber daya untuk dievaluasi serta memperoleh gambaran yang jelas tentang situasi dan memastikan pemahaman yang benar atasnya, (2) brainstorm dan merencanakan proses solusi. Brainstorming adalah melihat situasi beserta perubahannya, serta memperkirakan konsekuensi dari perubahan tersebut, (3) mengimplementasikan solusi. Setelah serangkaian langkah diidentifikasi, perlu dilihat hasil dari tiap langkah untuk memastikan bahwa langkah-langkah yang diambil sejauh ini menghasilkan hasil yang diinginkan, dan (4) memeriksa hasil. Setelah solusi dicapai, perlu diperiksa kembali untuk memastikan bahwa hasil yang dicapai sudah sesuai dengan tujuan yang ditetapkan ${ }^{[3]}$.

Meskipun sudah terdapat langkah-langkah umum dan strategi-strategi umum untuk menyelesaikan suatu masalah seperti tersebut di atas, namun tidak berarti seseorang tidak menemui kendala dalam mempraktekkannya. Beberapa kendala yang mungkin ditemui seseorang dalam menyelesaikan masalah antara lain menyangkut salah interpretasi, ukuran masalah, dan motivasi ${ }^{[4]}$.

Hedge menyatakan bahwa salah satu parameter gangguan belajar siswa adalah kurangnya mekanisme umpan balik yang dinamis dari buku teks. Ia juga menyimpulkan dalam penelitiannya seringkali siswa gagal untuk membangun ide-ide mereka di luar definisi dan pernyataan hukum yang dicontohkan dalam konteks pemecahan masalah. Kemampuan pemecahan masalah tidak perlu muncul sebagai konsekuensi dari kejelasan konseptual saja. Oleh karena itu, pelatihan dalam pemecahan masalah fisika dapat membantu siswa untuk memperoleh keterampilan yang dibutuhkan. Juga, pembentukan kerangka prosedural pemecahan masalah fisika membutuhkan pemahaman dan keterampilan yang lebih ${ }^{[5]}$.

Amalia menemukan bahwa pemecahan masalah yang dianggap penting, baik oleh para guru maupun siswa disemua tingkatan, ternyata dianggap sebagai bagian tersulit dalam proses belajar mengajar, baik bagi siswa dalam proses belajar maupun bagi guru dalam proses mengajar ${ }^{[6]}$.

Penelitian-penelitian yang mengkaji tentang problem solving menemukan bahwa siswa memiliki kelemahan dalam pemecahan 
masalah. Sebagai contoh, penelitian yang dilakukan oleh Bradyang menemukan bahwa kebanyakan siswa menerapkan beberapa strategi mendasar, seperti melihat kembali permasalahan yang sejenis, membaca pernyataan masalah tersebut berulang kali bahkan menerapkan metode berbeda bergantung pada bagian-bagian dari permasalahan tersebut ${ }^{[7]}$ dan menurut penelitian yang dilakukan Zeith, para siswa memiliki kelemahan dalam menghubungkan simbol, kecenderungan untuk melihat persamaan dalam fisika hanya sebagai persamaan matematis, juga kurangnya keterampilan manipulasi matematika ${ }^{[8]}$.

Faktor penting dalam menentukan produktivitas jawaban yang dihasilkan yaitu penggunaan waktu dalam langkah-langkah problem solving, memahami dan melaksanakan langkah-langkah dalam problem solving. Namun dalam kenyataannya, seringkali para siswa mengabaikan tahapan-tahapan penting dalam problem solving. Siswa seringkali terjebak pada tahap tiga saja, sering melupakan tahap empat dan mengabaikan tahap satu dan tahap dua. Selanjutnya untuk mengetahui apakah siswa menerapkan langkah-langkah problem solving, serta bagaimana produktivitas langkah-langkah siswa dalam melakukan physics problem solving, perlu dilakukan kajian lapangan melalui penelitian ini.

\section{METODE PENELITIAN}

Penelitian ini merupakan penelitian kualitatif, yaitu peneliti mengumpulkan data dengan cara langsung melalui observasi/pengamatan. Penelitian ini menggunakan metode penelitian deskriptif, yang bertujuan untuk mendeskripsikan produktivitas langkah-langkah siswa dalam memecahkan masalah yang meliputi kemampuan memahami masalah, merencanakan penyelesaian, menyelesaikan dan mengecek kembali penyelesaian yang diperoleh dari masalah yang diberikan.

Desain/rancangan dalam penelitian ini yaitu dilakukan tes menggunakan multiple choice question untuk memilih responden. Responden yang terpilih diberi tes problem solving dalam format one-on-one thinking-aloud yang dirangkaikan dengan semi-structured interview dan selanjutnya dari data-data yang diperoleh dari kegiatan di atas dianalisis.
Penentuan responden dilakukan dengan cara memberikan soal pilihan ganda sebagai tes seleksi responden.

Peneliti melakukan pengamatan atau interaksi secara langsung dengan subyek penelitiannya dalam lingkungan subyek penelitian itu sendiri yang berlangsung pada saat pemberian tes seleksi responden hingga pengambilan data melalui kegiatan thinking-aloud dan wawancara.

Analisis data dari jawaban tes soal fisika yaitu setiap tahap dianalisis produktivitas langkahlangkah siswa dalam memecahkan masalah yang diberikan.

\section{HASIL DAN PEMBAHASAN}

\subsection{Langkah-langkah problem solving}

Transkrip thinking-aloud dibaca berulangulang dan mendengar beberapa kali rekamannya, membandingkan dengan lembar jawaban responden serta menyimak transkrip hasil wawancara diperoleh gambaran tentang langkah-langkah siswa dalam physics problem solving dengan produtiktivitas dari langkahlangkah siswa dalam physics problem solving.

1) Langkah-langkah problem solving siswa pada soal tentang jarak dan perpindahan

Uraian tahapan problem solving yang dilakukan responden dapat dilihat pada transkrip thinking-aloud pada Tabel 1 Kutipan jawaban tertulis R-01 disajikan pada gambar 1 .

Langkah pertama yang dilakukan R-01 dalam memulai problem solving yaitu dengan menggambar kembali gambar yang ada pada soal yang dapat digunakan sebagai bantuan. Kemudian memahami masalah dengan menentukan variabel, lalu R-01 langsung menyelesaikan masalah tetapi tidak secara sistematis kemudian menyimpulkan diakhir menemukan jawaban.

Sebagian besar responden yang melakukan problem solving pada soal nomor satu sudah mampu mengidentifikasi informasi yang ada pada soal, walaupun beberapa responden hanya mampu menginterpretasi sebagian dari informasi yang diberikan pada soal. Dalam hal penggunaan langkah-langkah problem solving sebagian responden masih sulit memilih langkah-langkah yang tepat untuk digunakan dalam melakukan problem solving berdasarkan dari informasi yang diberikan. 
Tabel 1 Langkah-Langkah Problem Solving Responden R-01

\begin{tabular}{|c|c|c|}
\hline Transkrip & $\begin{array}{l}\text { Langkah- } \\
\text { langkah } \\
\text { problem } \\
\text { solving }\end{array}$ & $\begin{array}{l}\text { Kategori } \\
\text { langkah } \\
\text { problem } \\
\text { solving } \\
\end{array}$ \\
\hline $\begin{array}{l}\text {.. [Membaca keseluruhan } \\
\text { soal] \{membaca soal }\} \\
\text { [mengulang membaca } \\
\text { soal]. Kita gambarkan } \\
\text { Jarak a ke b } 7 \mathrm{~m} \text {, b ke d } \\
=7 \mathrm{~m} \text {. Mula-mula dititik a } \\
\text { dengan rute berbeda } 1 \\
\text { pelari jaraknya } 7 \mathrm{~m} \text { ini } \\
6 \mathrm{~m} \text {. a-c }=6 \mathrm{~m} \text {. Terus } \\
\text { jarak kedua jarak a ke b } \\
=7 \mathrm{~m} \text {. Kedua pelari ini } \\
\text { sama-sama menuju } \\
\text { ketitik d. }\end{array}$ & $\begin{array}{l}\text { Membuat } \\
\text { gambar } \\
\text { Menentuka } \\
\text { n variabel } \\
\text { yang } \\
\text { diketahui } \\
\text { dan } \\
\text { ditanyakan } \\
\text { dari soal }\end{array}$ & $\begin{array}{l}\text { Memahami } \\
\text { masalah }\end{array}$ \\
\hline $\begin{array}{l}\text { Jadi kita jumlahkan } \\
\text { jarak a ke c tambah jarak } \\
\text { c ke d }=6+8=14 \mathrm{~m} \\
\text { untuk pelari pertama. } \\
\text { Terus pelari kedua jarak } \\
\text { a ke b tambah jarak b ke } \\
\mathrm{d}=7+7=14 \mathrm{~m} \text {. }\end{array}$ & $\begin{array}{l}\text { - Merencana } \\
\text { kan } \\
\text { strategi } \\
\text { penyelesai } \\
\text { an } \\
\text { masalah }\end{array}$ & $\begin{array}{l}\text { Menyusun } \\
\text { rencana } \\
\text { penyelesaia } \\
\mathrm{n}\end{array}$ \\
\hline $\begin{array}{l}\text { Bila kelajuan kedua pelari } \\
\text { itu sama, maka siapa } \\
\text { yang akan sampai duluan } \\
\text { ketitik c <... Kedua } \\
\text { pelari sampai ke titik d } \\
\text { secara bersama-sama } \\
\text { karena jarak a ke d } \\
\text { melalui titik b sama } \\
\text { dengan jarak a ke d } \\
\text { melalui titik c. }\end{array}$ & $\begin{array}{l}\text { - Menuliskan } \\
\text { penyelesai } \\
\text { an } \\
\text { masalah } \\
\text { dari soal }\end{array}$ & $\begin{array}{l}\text { Melaksanak } \\
\text { an rencana } \\
\text { penyelesaia } \\
\mathrm{n}\end{array}$ \\
\hline $\begin{array}{l}\text { Kemudian besarnya } \\
\text { perpindahan } \\
\text { dilakukan pelari yang } \\
\text { melalui titik } \mathrm{c}\langle\ldots\rangle \text {. }\end{array}$ & $\begin{array}{l}\text { - Menentuka } \\
\text { n variabel } \\
\text { yang } \\
\text { ditanyakan } \\
\text { dari soal } \\
\text { bagian b }\end{array}$ & $\begin{array}{l}\text { Memahami } \\
\text { masalah }\end{array}$ \\
\hline $\begin{array}{l}\text { perpindahannya } 8 \mathrm{~m}-6 \mathrm{~m} \\
=2 \mathrm{~m} .\end{array}$ & $\begin{array}{l}\text { - Menyelesai } \\
\text { kan } \\
\text { masalah }\end{array}$ & $\begin{array}{l}\text { Menyelesai } \\
\text { kan } \\
\text { masalah } \\
\text { sesuai } \\
\text { rencana }\end{array}$ \\
\hline $\begin{array}{l}\text { jadi perpindahan yang } \\
\text { dia lakukan yaitu } 2 \mathrm{~m} \text {. }\end{array}$ & $\begin{array}{l}\text { - Menyimpul } \\
\text { kan } \\
\text { jawaban }\end{array}$ & $\begin{array}{l}\text { Menyimpul } \\
\text { kan }\end{array}$ \\
\hline
\end{tabular}

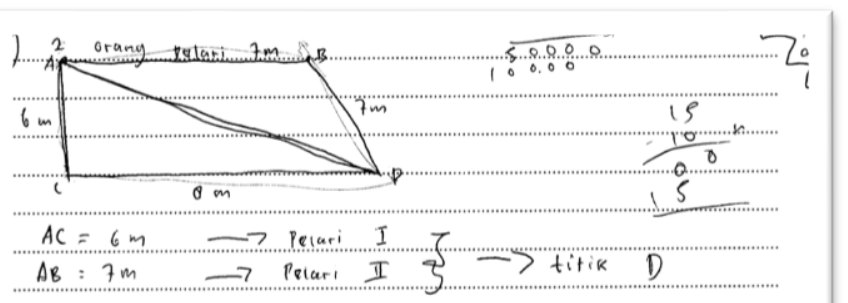

$A C+C D=6 m+8 m=14 m \longrightarrow P_{\text {eluri }} \longrightarrow$ $A B+B D=7 m+7 m=14 m \longrightarrow$ Pelarl II Kedua Pelari akan sampai $k e$ titik $D$ secara bersama Karena Jarak $A \rightarrow B \rightarrow D$ sama dangan Jarak $A \rightarrow C \rightarrow D$ - Besarnya Perpindanun yany dilukukan Plari

2) Langkah-langkah problem solving siswa pada soal tentang formulasi hubungan perpindahan, percepatan, dan waktu

Uraian tahapan problem solving yang dilakukan responden dapat dilihat pada transkrip thinking-aloud pada Tabel 2 dan Kutipan jawaban pada Gambar 2.

Tabel 2 Langkah-Langkah Problem Solving Responden R$\underline{05}$

\begin{tabular}{|c|c|c|}
\hline Transkrip & $\begin{array}{c}\text { Langkah- } \\
\text { langkah } \\
\text { problem } \\
\text { solving }\end{array}$ & $\begin{array}{c}\text { Kategori } \\
\text { langkah } \\
\text { problem } \\
\text { solving }\end{array}$ \\
\hline $\begin{array}{l}\ldots[\text { membaca } \\
\text { keseluruhan soal] } \\
\{\text { membaca soal }\} \\
\text { kecepatannya }= \\
<\ldots>\mathrm{v}=15 \mathrm{~m} / \mathrm{s}, \mathrm{s} \\
=50-40=10 . \\
\text { Ditanyakan waktu. } \\
\mathrm{t}=\mathrm{v} / \mathrm{s}, \text { eh bukan } \\
{[\text { mencoret }} \\
\text { persamaan], } \mathrm{t}=\mathrm{v} \\
\text { dikali } \mathrm{s} \\
=10 \times 15 \\
=150 \text { sekon }\end{array}$ & $\begin{array}{l}\text { - Merencanakan } \\
\text { strategi } \\
\text { penyelesaian } \\
\text { masalah } \\
\text { - Menghitung } \\
\text { - Menuliskan } \\
\text { penyelesaian } \\
\text { masalah dari } \\
\text { soal } \\
\end{array}$ & $\begin{array}{l}\text { Menyusun } \\
\text { rencana } \\
\text { penyelesaian } \\
\text { Menyelesaikan } \\
\text { masalah } \\
\text { sesuai rencana }\end{array}$ \\
\hline
\end{tabular}

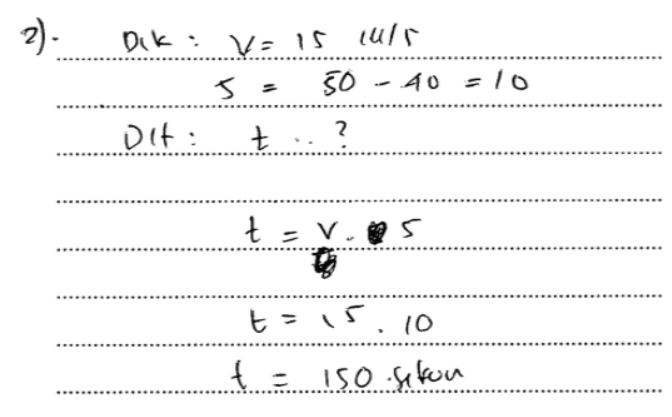

Gambar 2. Kutipan jawaban R-05

R-05 memulai problem solving dengan membaca soal dan menentukan variabel, kemudian ia diam sejenak lalu memutuskan melakukan langkah penyelesaian hanya dengan variabel yang ia temukan pada soal tanpa memikirkan penyelesaian lain yang lebih 
relevan, kemudian menghitung hasilnya. Responden kurang mampu menginterpretasi informasi yang diberikan pada soal nomor dua secara tepat. Ketidakmampuan interpretasi ini menyebabkan sebagian besar responden tidak mampu menyusun langkah-langkah problem solving yang tepat. Dari transkrip thinkingaloud dapat diketahui bahwa siswa tidak memahami situasi yang dimaksud dalam soal.

3) Langkah-langkah problem solving siswa pada soal tentang gerak benda jatuh bebas dibawah pengaruh gravitasi.

Uraian tahapan problem solving yang dilakukan responden dapat dilihat pada transkrip thinking-aloud pada Tabel 3 dan Kutipan jawaban pada Gambar 3.

Tabel 3 Langkah-Langkah Problem Solving Responden R-04

\begin{tabular}{|c|c|c|}
\hline Transkrip & $\begin{array}{l}\text { Langkah- } \\
\text { langkah } \\
\text { problem } \\
\text { solving }\end{array}$ & $\begin{array}{l}\text { Kategori } \\
\text { langkah } \\
\text { problem } \\
\text { solving }\end{array}$ \\
\hline $\begin{array}{l}\ldots \text { [Membaca } \\
\text { keseluruhan soal] } \\
\{\text { membaca soal }\} \\
\text { diketahui } v=10 \mathrm{~m} / \mathrm{s} \mathrm{h} \\
=<\ldots>\text { apa ini yang } \\
\text { ditanya. Kapan orang } \\
\text { tersebut menyentuh } \\
\text { tanah, apa ini yang } \\
\text { ditanya e. }\end{array}$ & $\begin{array}{l}\text { Menentukan } \\
\text { variabel } \\
\text { yang } \\
\text { diketahui } \\
\text { dan } \\
\text { ditanyakan } \\
\text { dari soal }\end{array}$ & $\begin{array}{l}\text { Memahami } \\
\text { masalah }\end{array}$ \\
\hline $\begin{array}{l}\text { Apa yang ditanyakan } \\
\text { ini e. } v \text { sto, eh bukan. } \\
=(\vee \times g) / \mathrm{h}\end{array}$ & $\begin{array}{l}\text { - } \quad \text { Merencanak } \\
\text { an strategi } \\
\text { penyelesaian } \\
\text { masalah }\end{array}$ & $\begin{array}{l}\text { Menyusun } \\
\text { rencana } \\
\text { penyelesaia } \\
\mathrm{n}\end{array}$ \\
\hline $\begin{array}{l}(10 \mathrm{~m} / \mathrm{s} \times \\
\left.10 \mathrm{~m} / \mathrm{s}^{2}\right) / 15 \mathrm{~m}= \\
6,67 \mathrm{~m} / \mathrm{s}\end{array}$ & $\begin{array}{ll}\text { - } & \text { Menghitung } \\
& \text { Menuliskan } \\
\text { penyelesaian } \\
\text { masalah dari } \\
\text { soal }\end{array}$ & $\begin{array}{l}\text { Menyelesai } \\
\text { kan } \\
\text { masalah } \\
\text { sesuai } \\
\text { rencana }\end{array}$ \\
\hline
\end{tabular}

Responden R-04 dalam melakukan problem solving, dimulai dengan membaca soal kemudian mengidentifikasi informasi, namun ia kesulitan dalam menentukan variabel dalam masalah yang diberikan. Ia, kemudian memikirkan solusi dari masalah, kemudian melanjutkan lagi langkah problem solving dengan menyelesaikan masalah sesuai dengan yang ia pikirkan.

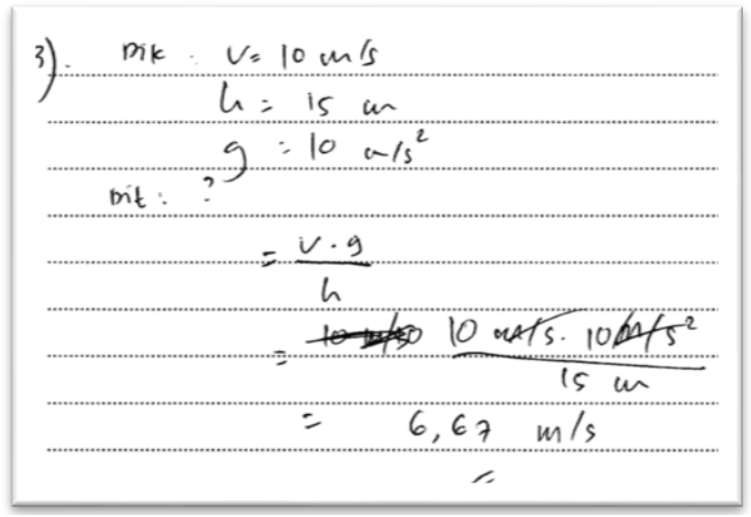

Gambar 3. Kutipan Jawaban R-04

Sebagian besar responden melakukan kekeliruan pada saat melakukan identifikasi informasi pada soal tentang gerak benda jatuh bebas dibawah pengaruh gravitasi, bahkan tidak mampu melakukan identifikasi terhadap permasalahan yang diberikan. Kekeliruan dan ketidakmampuan dalam mengidentifikasi informasi ini berdampak pada penggunaan strategi yang diperlukan dalam melakukan problem solving, yaitu hanya melakukan beberapa langkah-langkah problem solving.

Melalui transkrip thinking-aloud dapat diketahui bahwa siswa dapat memahami masalah dari soal namun karena keterbatasan penguasaan simbol membuat siswa bingung menyatakannya dalam simbol, sehingga mereka sulit menemukan perencanaan penyelesaian masalah yang baik dan benar.

4) Langkah-langkah problem solving siswa pada tentang soal analisis gerak lurus dengan kecepatan konstan

Uraian tahapan problem solving yang dilakukan responden dapat dilihat pada transkrip thinking-aloud pada Tabel 4 dan Kutipan jawaban pada Gambar 4.

Langkah-langkah problem solving yang dilakukan R-06 yaitu sesuai dengan langkahlangkah pemecahan masalah, R-06 memulai pemecahan masalah dengan membaca soal, memahami masalah dengan menuliskan yang diketahui dan ditanyakan dari soal, kemudian menyusun rencana penyelesaian, dalam menyusun rencana penyelesaian, R-06 menyusun strategi penyelesaian yang kurang relevan sehingga melaksanakan rencana penyelesaian yang salah, kemudian menyimpulkan.

Tabel 4 Langkah-Langkah Problem Solving Responden R-06

$\begin{array}{ccc}\text { Transkrip } & \begin{array}{c}\text { Langkah- } \\ \text { langkah }\end{array} & \begin{array}{l}\text { Kategori } \\ \text { langkah } \\ \text { problem }\end{array} \\ \text { problem }\end{array}$




\begin{tabular}{|c|c|c|}
\hline & solving & solving \\
\hline $\begin{array}{l}\text {... [membaca } \\
\text { keseluruhan soal] } \\
\{\text { membaca soal }\} \text { dari } \\
\text { soal dapat diketahui } \\
\text { kecepatan mobil A = } \\
72 \mathrm{~km} / \text { jam. Jarak mobil } \\
\text { B dengan mobil A = } \\
1,5 \mathrm{~km} . \text { Kecepatan } \\
\text { mobil B = 7km } / \text { jam. } \\
\text { Berapa waktu yang } \\
\text { diperlukan mobil B } \\
\text { untuk menyusul mobil } \\
\text { A. }\end{array}$ & $\begin{array}{l}\text { - Menentukan } \\
\text { variabel yang } \\
\text { diketahui dan } \\
\text { ditanyakan } \\
\text { dari soal }\end{array}$ & $\begin{array}{l}\text { Memahami } \\
\text { masalah }\end{array}$ \\
\hline $\begin{array}{l}<\ldots>1 \text { jam }=60 \text { menit } \\
=3600 \text { sekon. } 72 / 3600 \\
=0,02 \mathrm{~km} / \mathrm{s}\end{array}$ & $\begin{array}{l}\text { - Merencanaka } \\
\text { n strategi } \\
\text { penyelesaian } \\
\text { masalah }\end{array}$ & $\begin{array}{l}\text { Menyusun } \\
\text { rencana } \\
\text { penyelesaia } \\
\mathrm{n}\end{array}$ \\
\hline $\begin{array}{l}<\ldots>1,5: 0,02=75 \\
\text { sekon }\end{array}$ & $\begin{array}{l}\text { - Menghitung } \\
\text { - Menuliskan } \\
\text { penyelesaian } \\
\text { masalah dari } \\
\text { soal }\end{array}$ & $\begin{array}{l}\text { Melaksanak } \\
\text { an rencana } \\
\text { penyelesaia } \\
\mathrm{n}\end{array}$ \\
\hline $\begin{array}{l}\text { Kemudian, jadi waktu } \\
\text { yang dibutuhkan = } \\
\text { 75sekon }\end{array}$ & $\begin{array}{l}\text { - Menyimpulka } \\
\text { n jawaban }\end{array}$ & $\begin{array}{l}\text { Menyimpul } \\
\text { kan }\end{array}$ \\
\hline
\end{tabular}

9.) mobih $A=72 \mathrm{~km} / \mathrm{jam}$

Sarak mobic $B$ denam mobi $A=1,5 k$ ku mobil $A=7$ s kin/man

J $1 \mathrm{gm}=60$ menit $=3600 \mathrm{~s}$

$\frac{72}{3600}-0,02 \mathrm{~km} / \mathrm{s}=$

$1,5: 0.07=75 s$

Jadi waktu yang dibutulkan $=755$

Gambar 4. Kutipan jawaban R-06

Soal tentang analisis gerak gerak lurus dengan kecepatan konstan, sebagian besar responden tidak dapat mengidentifikasi informasi yang diberikan pada soal. Ketidakmampuan identifikasi informasi ini berdampak pada ketidakmampuan siswa dalam memilih langkah-langkah problem solving yang baik, bahkan para siswa tidak berusaha sama sekali untuk menentukan langkah-langkah yang mereka ambil dalam melakukan problem solving.

5) Langkah-langkah problem solving siswa pada soal tentang penerapan hukum fisika untuk gerak

Uraian tahapan problem solving yang dilakukan responden dapat dilihat pada transkrip thinking-aloud pada Tabel 5 dan Kutipan jawaban pada Gambar 5.

Tabel 5 Langkah-Langkah Problem Solving Responden R-02 Transkrip

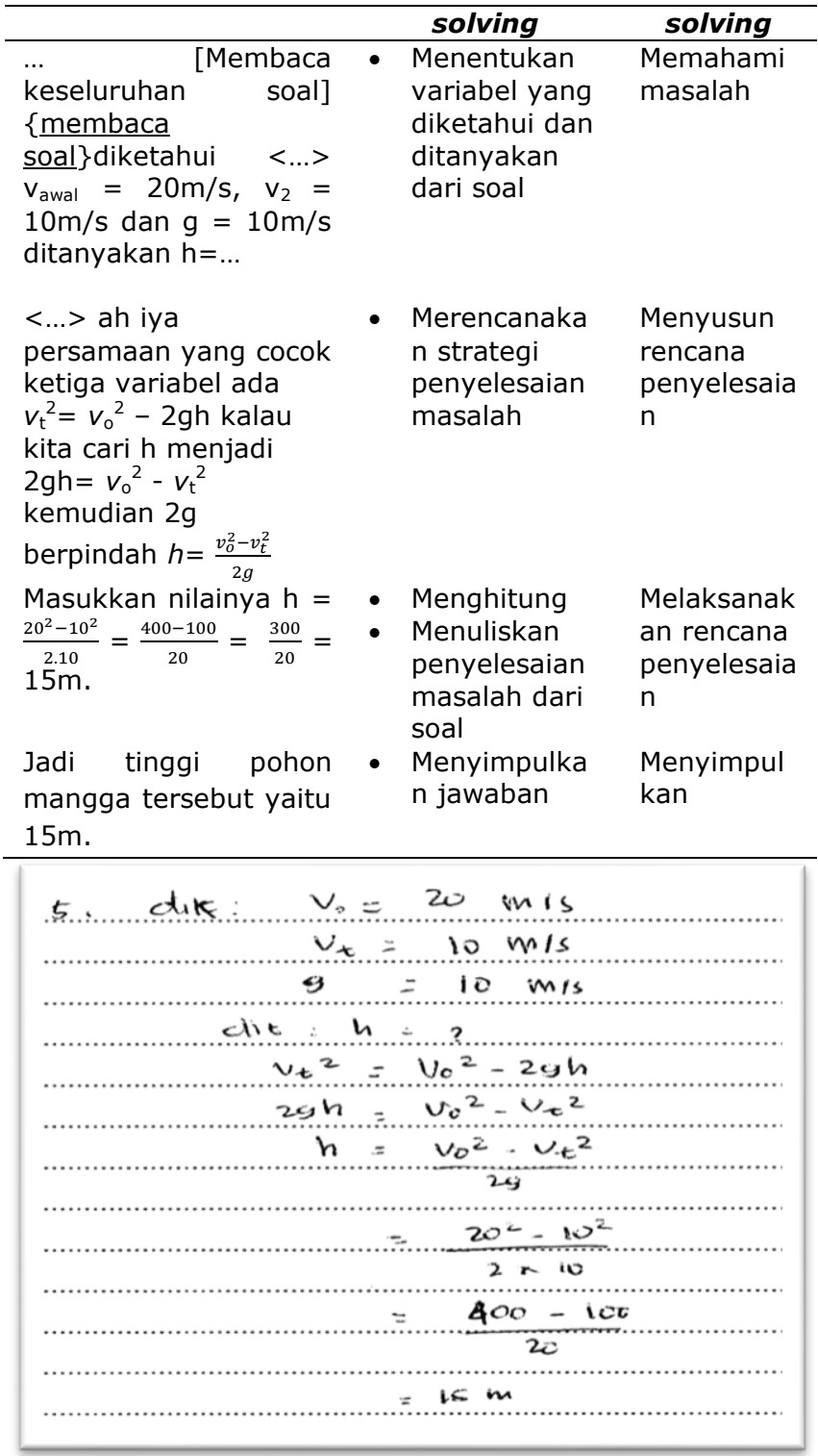

Gambar 5. Kutipan Jawaban R-02

R-02 melakukan langkah-langkah problem solving dengan baik dan menghasilkan jawaban yang benar. R-02 memulai problem solving dengan membaca soal, kemudian mengidentifikasi dan menuliskan apa yang diketahui dan ditanyakan dari soal. Selanjutnya R-02 merencanakan penyelesaian masalah dengan rencana strategi yang benar dan mengarah kepada jawaban yang benar. Kemudian R-02 menyelesaikan masalah sesuai rencana penyelesaian, benar lengkap dan sistematis menuliskan penyelesaian dari soal.

\subsection{Produktivitas Langkah-Langkah Siswa dalam Problem Solving}

Berdasarkan hasil analisis yang dilakukan pada saat siswa menjawab soal melalui kegiatan thinking-aloud dan melihat hasil 
jawaban yang mereka tuliskan dapat dilihat bahwa langkah-langkah siswa dalam melakukan problem solving kurang produktif. Siswa pada umumnya tidak melakukan pengecekan kembali jawaban, mereka hanya fokus pada menemukan jawaban. Distribusi langkahlangkah physics problem solving oleh siswa dan produktivitasnya dapat dilihat pada Tabel 6 . 
Tabel 6 Perolehan Skor Langkah-Langkah Problem Solving Responden

\begin{tabular}{|c|c|c|c|c|c|c|c|c|c|}
\hline \multirow[t]{2}{*}{ NO } & \multirow{2}{*}{$\begin{array}{l}\text { INISIAL } \\
\text { RESPON } \\
\text { DEN } \\
\end{array}$} & \multirow[t]{2}{*}{ TAHAPAN PENYELESAIAN } & \multicolumn{5}{|c|}{$\begin{array}{l}\text { PEROLEHAN SKOR LANGKAH- } \\
\text { LANGKAH PROBLEM SOLVING }\end{array}$} & \multirow{2}{*}{$\begin{array}{c}\text { TOTAL } \\
\text { PEROLEHAN } \\
\text { SKOR }\end{array}$} & \multirow{2}{*}{$\begin{array}{l}\text { NILAI AKHIR } \\
\text { LANGKAH } \\
\text { PROBLEM } \\
\text { Coumrnir }\end{array}$} \\
\hline & & & 1 & 2 & 3 & 4 & 5 & & \\
\hline \multirow{4}{*}{1} & \multirow{4}{*}{$R=01$} & Mengidentifikasi masalah & 2.5 & 2.5 & 2.5 & 2.5 & 2.5 & \multirow{4}{*}{29,50} & \multirow{4}{*}{43,82} \\
\hline & & Merencanakan penyelesaian masalah & 3.5 & 1.5 & 1.5 & 1.5 & 1.5 & & \\
\hline & & Menyelesaikan masalah sesuai rencana & 1.5 & 1.5 & 1.5 & 1.5 & 1.5 & & \\
\hline & & Memeriksa kembali hasil & & & & & & & \\
\hline \multirow{6}{*}{2} & \multirow{5}{*}{$\mathrm{R}-02$} & & 7,5 & 5,5 & 5,5 & 5,5 & 5,5 & \multirow{5}{*}{52,00} & \multirow{5}{*}{76,47} \\
\hline & & Mengidentifikasi masalah & 5 & 5 & 5 & 5 & 5 & & \\
\hline & & Merencanakan penyelesaian masalah & 4 & 4 & 4 & & 4 & & \\
\hline & & Menyelesaikan masalah sesuai rencana & 4 & 1.5 & & 1.5 & 4 & & \\
\hline & & Memeriksa kembali hasil & & & & & & & \\
\hline & & & 9 & 10,5 & 9 & 6,5 & 13 & \multirow{5}{*}{26,00} & \\
\hline \multirow{4}{*}{3} & \multirow{4}{*}{ R-04 } & Mengidentifikasi masalah & 1 & 2.5 & 4 & 4 & 1 & & \multirow{4}{*}{38,23} \\
\hline & & Merencanakan penyelesaian masalah & & 1.5 & 1.5 & 1.5 & 1.5 & & \\
\hline & & Menyelesaikan masalah sesuai rencana & 1.5 & 1.5 & 1.5 & 1.5 & 1.5 & & \\
\hline & & Memeriksa kembali hasil & & & & & & & \\
\hline \multirow{6}{*}{4} & \multirow{6}{*}{ R-05 } & & 2,5 & 5,5 & 7 & 7 & 4 & \multirow{5}{*}{30,50} & \multirow{5}{*}{44,85} \\
\hline & & Mengidentifikasi masalah & 3 & 4 & 4 & 1 & 2 & & \\
\hline & & Merencanakan penyelesaian masalah & 1.5 & 1.5 & 1.5 & 1.5 & 1.5 & & \\
\hline & & Menyelesaikan masalah sesuai rencana & 3 & 1.5 & 1.5 & 1.5 & 1.5 & & \\
\hline & & Memeriksa kembali hasil & & & & & & & \\
\hline & & & 7,5 & 7 & 7 & 4 & 5 & \multirow{5}{*}{23,00} & \multirow{5}{*}{33,82} \\
\hline \multirow{5}{*}{5} & \multirow{5}{*}{$R-06$} & Mengidentifikasi masalah & & & 1 & 2 & & & \\
\hline & & Merencanakan penyelesaian masalah & 1.5 & 1.5 & 1.5 & 1.5 & 1.5 & & \\
\hline & & Menyelesaikan masalah sesuai rencana & 4 & 4 & 1.5 & 1.5 & 1.5 & & \\
\hline & & Memeriksa kembali hasil & & & & & & & \\
\hline & & & 5,5 & 5,5 & 4 & 5 & 3 & & \\
\hline \multirow{2}{*}{\multicolumn{3}{|c|}{$\begin{array}{l}\text { Jumlah skor setiap soal } \\
\text { skor maksimum }\end{array}$}} & 36 & 34 & 32,5 & 28 & 30,5 & & \\
\hline & & & 85 & 85 & 85 & 85 & 85 & & \\
\hline \multicolumn{3}{|c|}{ persentase pada setiap soal (\%) } & 48,35 & 40,00 & 38,23 & 32,94 & 35,88 & & \\
\hline
\end{tabular}

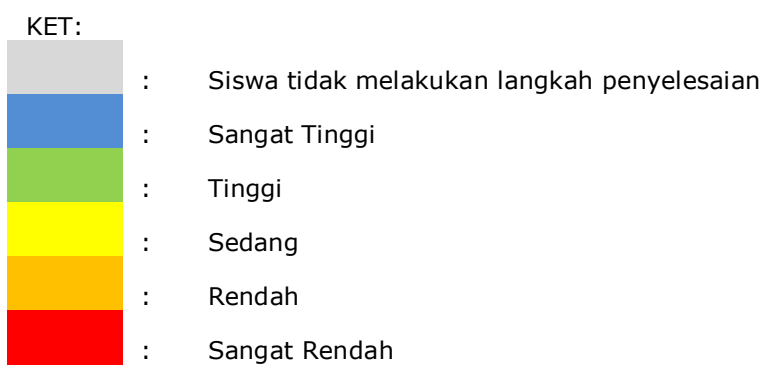

Berdasarkan tabel di atas dapat dilihat bahwa produktivitas siswa dalam melakukan langkah-langkah problem solving setiap siswa masih rendah. Setiap siswa melakukan langkah-langkah problem solving hingga mendapatkan hasil akhir, namun melakukan perencanaan strategi penyelesaian yang kurang relevan sehingga mengarah kepada jawaban yang keliru. Hal ini disebabkan karena siswa hanya fokus dalam menemukan jawaban sehingga tidak memperhatikan langkah-langkah penting dalam problem solving seperti mengidentifikasi variabel dan memeriksa kembali hasil jawaban.

Berdasarkan penelitian yang dilakukan oleh Pribul dan Bodner, mereka menyimpulkan bahwa tahap awal dalam problem solving yang melibatkan pengumpulan informasi yang relevan dan restrukturisasi masalah menjadi bagian-bagian yang lebih kecil sehingga lebih mudah dipahami merupakan hal yang sangat penting dan menentukan keberhasilan atau kegagalan proses problem solving. Hal ini juga menunjukkan bahwa rendahnya produktivitas siswa dalam melakukan problem solving disebabkan karena siswa mengabaikan tahap awal dalam problem solving yang merupakan hal sangat penting penentu keberhasilan atau kegagalan proses problem solving ${ }^{[9]}$.

Tabel 6 terlihat bahwa responden R-01 dan R-05 melakukan langkah-langkah problem solving dengan baik, tetapi memiliki skor jawaban problem solving yang berbeda. Untuk soal tentang jarak dan perpindahan, total skor yang dicapai keseluruhan adalah 36 atau sebesar $48,35 \%$ dari total skor maksimum langkah-langkah problem solving yang bisa dicapai secara keseluruhan (85).

Untuk soal tentang formulasi hubungan perpindahan, kecepatan, dan waktu, total skor yang dicapai adalah 34 atau sebesar 40,00\% dari total skor maksimum langkah-langkah problem solving yang bisa dicapai secara keseluruhan (85). Untuk soal tentang gerak benda jatuh bebas dibawah pengaruh gravitasi, total skor yang dicapai adalah 32,5 atau sebesar $38,23 \%$ dari total skor maksimum langkah-langkah problem solving yang bisa dicapai secara keseluruhan (85). Untuk soal tentang analisis gerak lurus dengan kecepatan konstan, total skor yang dicapai adalah 28 atau sebesar $32,94 \%$ dari total skor maksimum langkah-langkah problem solving yang bisa dicapai secara keseluruhan (85).

Pada soal tentang formulasi hubungan perpindahan, kecepatan, dan waktu, dan soal tentang gerak jatuh bebas dibawah pengaruh gravitasi, serta soal tentang analisis gerak lurus dengan kecepatan konstan, sebagian besar para siswa berusaha melakukan problem solving dengan menggunakan rumus-rumus dasar dengan langkah penyelesaian masalah yang seadanya, seperti yang dikemukakan oleh Suherman ${ }^{[2]}$ bahwa suatu masalah biasanya memuat suatu situasi yang mendorong seseorang untuk menyelesaikannya akan tetapi tidak tahu secara langsung apa yang harus dikerjakan untuk menyelesaikannya.

Untuk soal tentang penerapan hukum fisika untuk gerak, total skor yang dicapai adalah 30,5 atau sebesar $35,88 \%$ dari total skor maksimum langkah-langkah problem solving yang bisa dicapai secara keseluruhan (85). Berdasarkan hasil penelitian dapat diketahui 
bahwa para siswa kurang mampu dalam mengidentifikasi secara tepat seluruh informasi yang diberikan pada soal. Hal ini berdampak pada pemilihan langkah-langkah dalam melakukan problem solving, seperti yang dikemukakan oleh Dominowski bahwa beberapa kendala yang mungkin ditemui seseorang dalam menyelesaikan masalah antara lain menyangkut salah interpretasi, ukuran masalah, dan interpretasi ${ }^{[4]}$.

Berdasarkan penjelasan di atas dapat dilihat bahwa produktivitas langkah-langkah problem solving siswa masih kurang sehingga langkah problem solving siswa berbeda-beda yang menghasilkan produktivitas yang berbeda pula. Hal ini disebabkan ketidakmampuan siswa dalam mengidentifikasi informasi dari permasalahan yang diberikan yang menyebabkan kekeliruan dalam menentukan langkah-langkah problem solving. Hal ini sejalan dengan penelitian Brad yang menemukan bahwa kebanyakan siswa menerapkan beberapa strategi mendasar, seperti melihat kembali permasalahan yang sejenis, membaca pernyataan masalah tersebut berulang kali bahkan menerapkan metode berbeda bergantung pada bagian-bagian permasalahan tersebut ${ }^{[7]}$.

\section{KESIMPULAN}

Berdasarkan hasil analisis data dan pembahasan maka dapat disimpulkan bahwa siswa melakukan langkah-langkah yang bervariasi dalam melakukan problem solving. Sebagian besar siswa fokus pada hasil akhir dan kurang memperhatikan langkah-langkah penyelesaian masalah sehingga produktivitas dari physics problem solving juga rendah.

\section{DAFTAR PUSTAKA}

[1] Polya, G. (1957). "How To Solve it" [online]. Tersedia. http://www.ccs.neu.edu/home/lieber/courses/material s/Polya_Father_of_problemSolving.pdf [desember 2013].

[2] Suherman, E, dkk. (2003). Strategi Pembelajaran Matematika Kontemporer. Bandung: UPI dan IMSTEP JICA.

[3] Ikhwanuddin. (2010)" Problem Solving dalam Pembelajaran Fisika untuk Meningkatkan Kemampuan Mahasiswa Berpikir Analitis". Jurnal Kependidikan. 40, (2), 215-230.

[4] Dominowski, R.L. (2002). Teaching Undergraduates. New Jersey: Lawrence Erlbaum Assosiates Publishers.

[5] Hegde, B. (2012). "How Do They Solve It? An Insight Into The Learner's Approach To The Mechanism of
Physics Problem Solving". Physical Review Special Topics - Physics Education Research.

[6] Amalia, S. (2011). Analisis kemampuan pemecahan masalah matematis siswa SMA. Skripsi pada Jurusan Pendidikan Matematika FMIPA, Universitas Pendidikan Indonesia Bandung: tidak diterbitkan.

[7] Brad, A. (2011). "A Study of The Problem Solving Activity in High School Students: Strategies and SelfRegulated learning" Acta Didacta Napocensia. 4, (1), 21-30.

[8] Zeitz, P. (2007). The Art and Craft of Problem Solving. [Online].Tersedia: http:// Matematika/EBOOKS/ADVANCED/PaulZeitz(Author)Th eArtandCraftofProlemSolving (2Ed, Wiley,2006).pdf [24 mei 2015]

[9] Pribul, J.R and Bodner, G. M. 1987. Spatial Abilityand its Role in Organic chemistry: A Study of Four Organic courses. Journal of Reseach in science Teaching, 24, 229-240. 